Piotr STRZELCZYK ${ }^{1}$

Mariusz SZEWCZYK ${ }^{2}$

Rafał GAŁEK ${ }^{3}$

Pawel GIL ${ }^{4}$

\title{
MEASUREMENT OF SOLAR RADIATION PROPERTIES AND THERMAL ENERGY OF THE ATMOSPHERE IN RZESZOW
}

\begin{abstract}
This article presents measurement of solar radiation properties and thermal energy of the atmosphere in Rzeszów ( $\left.\varphi=50^{\circ} 02^{\prime} \mathrm{N}, \lambda=22^{\circ} 17^{\prime} \mathrm{E}\right)$. The measurements include direct, diffuse and global solar radiation as well as thermal radiation from the atmosphere. Weather station provides six of the most important weather parameters: air pressure, temperature, humidity, rainfall, speed and direction. Sky radiometer with dedicated sun tracker provides multiband measurement of direct and diffuse solar radiation. Measurement results from over 4 years have been collected so far and may be used to estimate energy yields from solar systems. The article presents selected results of solar radiation and weather parameters in 2017.
\end{abstract}

Keywords: solar radiation, renewable energy, weather, atmosphere

\section{Introduction}

As populations expand, living standards improve, consumption rises and total demand for energy increases. At the same time, growing concerns over climate change are promoting governments worldwide to look for ways to supply energy while minimizing greenhouse gas emissions. Renewable energy is energy that is collected from renewable sources that have the ability to naturally replenish on a human timescale. That includes solar, wind, water, certain types of biomass and geothermal energy. They have the potential to replace conventional fossil fuels in the future. Renewable energy sources exist over wide geographical areas, in contrast to other energy sources, which are concentrated in a limited number of countries. Widespread deployment of renewable energy systems results in significant

\footnotetext{
1 Author for correspondence/autor do korespondencji: Piotr Strzelczyk, Politechnika Rzeszowska, 8 Powstańców Warszawy Ave., 35-959 Rzeszów, tel.: (17) 8651352, e-mail: piotstrz@ prz.edu.pl

2 Mariusz Szewczyk, Politechnika Rzeszowska, e-mail: szewmar@prz.edu.pl

${ }^{3}$ Rafał Gałek, Politechnika Rzeszowska, e-mail: rafalgalek@ prz.edu.pl

${ }^{4}$ Paweł Gil, Politechnika Rzeszowska, e-mail: gilpawel@prz.edu.pl
} 
improvement of energy security, climate change mitigation, and economic benefits. There are a number of technologies for utilizing renewable energy and for improving energetic efficiency such as photovoltaics (PVs) [1-3], wind turbines [4-5], water turbines [6-7], cogeneration [8-10] and biomass burning [11-12].

Solar energy conversion systems can be divided into three categories according to their primary energy product: solar electricity, solar fuels, and solar thermal energy. The challenge in converting sunlight to electricity via photovoltaic solar cells is to reduce the cost/watt of delivered solar electricity. Modern materials that allow absorbing sunlight efficiently, new techniques to harness the full spectrum of wavelengths in solar radiation and new approaches based on nanostructured architectures can improve the technology used to produce solar electricity. The technological development and successful commercialization of singlecrystal solar cells demonstrates the social demand and market potential of PV technology. Novel approaches exploiting, thin films, organic semiconductors, and quantum dots offer fascinating new opportunities for cheaper, more efficient, longer-lasting systems. The key challenge in solar thermal technology is to identify cost-effective methods to convert sunlight into storable thermal energy. Reactors heated by focused, concentrated sunlight in thermal towers reach temperatures exceeding $3000^{\circ} \mathrm{C}$, enabling the efficient chemical production of fuels from raw materials without expensive catalysts [13].

It is extremely important to know the thermal parameters of the surroundings, weather and solar radiation properties in a given location in order to design and improve systems utilizing renewable energy sources. Accurate measurements of the solar radiation intensity are needed to determine the performance and efficiency of different type of solar and PV systems [1-3].

The purpose of this article is to present the research capabilities and selected measurement results of existing laboratory in characterization of solar radiation and atmosphere properties.

\section{Experimental setup}

The laboratory for measurement of solar radiation properties and thermal energy of the atmosphere was founded in November 2013. The purchase was funded with UE grants. The steel structure that supports measuring devices is installed on the roof of the building. The lab is located in Rzeszow $\left(\varphi=50^{\circ} 02^{\prime} \mathrm{N}\right.$, $\lambda=22^{\circ} 17^{\prime} \mathrm{E}$ ) and it is a part of the laboratory equipment for renewable energy devices performance investigation.

Incoming short-wave solar radiation can be divided into direct, diffuse and global components. Radiation from the sun is mainly in the "short-wave" range from 300 to $4000 \mathrm{~nm}$ that includes the visible, ultraviolet and near infrared wavelengths. A portion of this radiation is absorbed by clouds and aerosols in the atmosphere, which warms up and radiates long-wave radiation $(4.5 \mu \mathrm{m}$ to beyond 
$40 \mu \mathrm{m})$. Direct solar radiation is measured with pyrheliometer directed at the centre of the sun disk. The CHP 1 Kipp\&Zonen pyrheliometer has a full opening angle of $5^{\circ}$ and measures the normally incident direct irradiance from the sun and its aureole. The CHP1 has a spectral range (50\% points) from 200 to $4000 \mathrm{~nm}$ and operational temperature range from $-40^{\circ} \mathrm{C}$ to $+80^{\circ} \mathrm{C}$. Part of the radiation from the sun is absorbed and scattered by clouds and aerosols. This scattered component is the diffuse solar radiation measured with CMP 22 Kipp\&Zonen pyranometer with shading ball. This pyranometer can see the complete sky hemisphere, but the direct radiation from the sun is blocked by a shading ball that moves with a sun tracker. Another CMP 22 Kipp\&Zonen pyranometer measures global radiation (both the direct and diffuse radiation). The CMP 22 pyranometer has spectral range (50\% points) from 200 to $3600 \mathrm{~nm}$, maximum solar irradiance $4000 \mathrm{~W} / \mathrm{m}^{2}$, operational temperature range $-40^{\circ} \mathrm{C}$ to $+80^{\circ} \mathrm{C}$ and field of view $180^{\circ}$. For measuring incoming thermal radiation from the sky and clouds CGR4 Kipp \& Zonen pyrgeometer is used. It has spectral range (50\% points) 4.5 to $42 \mu \mathrm{m}$, operational temperature range $-40^{\circ} \mathrm{C}$ to $+80^{\circ} \mathrm{C}$ and field of view $180^{\circ}$. Net irradiance range for CGR4 is -250 to $250 \mathrm{~W} / \mathrm{m}^{2}$.

The Kipp \& Zonen Solys2 sun tracker is used to drive aforementioned sun sensors. It is the most widely used sun tracker around the world in solar energy and meteorological applications. The sun tracker has integrated GPS receiver to automatically configure location and time data upon installation. The operating temperature range from $-40^{\circ} \mathrm{C}$ to $+50^{\circ} \mathrm{C}$ using the standard internal heater. The pointing accuracy is better than $<0.1^{\circ}$, maximum payload is $20 \mathrm{~kg}$ (Fig. 1).

The CSD3 sunshine duration sensor is used for the measurement of sunshine duration. Sunshine duration is defined by WMO (World Meteorological Organization) as the time during which the direct solar radiation exceeds the level of $120 \mathrm{~W} / \mathrm{m}^{2}$. The output is switched high or low to indicate whether this condition is satisfied.

The Vaisala WXT536 is the compact weather station that provides six of the most important weather parameters: air pressure, temperature, humidity, rainfall, wind speed and direction. The barometric pressure can be measured within a range from 600 to $1100 \mathrm{hPa}$ with an accuracy of $\pm 1 \mathrm{hPa}$ at $-51^{\circ} \mathrm{C}$ to $+60^{\circ} \mathrm{C}( \pm 0.5 \mathrm{hPa}$ from $0^{\circ} \mathrm{C}$ to $30^{\circ} \mathrm{C}$ ). The outside air temperature can be measured in the range from $-51^{\circ} \mathrm{C}$ to $+60^{\circ} \mathrm{C}$ with accuracy $\pm 0.3^{\circ} \mathrm{C}$. Relative humidity can be measured in the range from $0 \ldots 100 \% \mathrm{RH}$ with accuracy $\pm 3 \% \mathrm{RH}$. Wind characteristics include the measurement of the velocity in the range of $0 \ldots 60 \mathrm{~m} / \mathrm{s}$ with an accuracy of $\pm 3 \%$ and detection of wind direction in the range of $0 \ldots 360^{\circ}$. The Vaisala allows rainfall and hail accumulation measurements with output resolution $0.01 \mathrm{~mm}$ and daily accuracy better than $5 \%$.

The PREDE POM-01 is a sky radiometer with dedicated sun tracker. It uses a single photo-diode detector and rotating filter wheel to measure radiation in seven narrow wavebands from $315 \mathrm{~nm}$ to $1020 \mathrm{~nm}$. The instrument has a sun sensor for active tracking (Fig. 1). The POM-01 sky radiometer provides multi-band 
measurement of direct and diffuse solar radiation. POM-01 is used in the Asia-Pacific SKYNET network for aerosol monitoring and satellite ground-truthing around the world [13]. The POM data can be post-processed to provide parameters including aerosol optical depth, scattering coefficients, aerosol distribution and energy distribution.

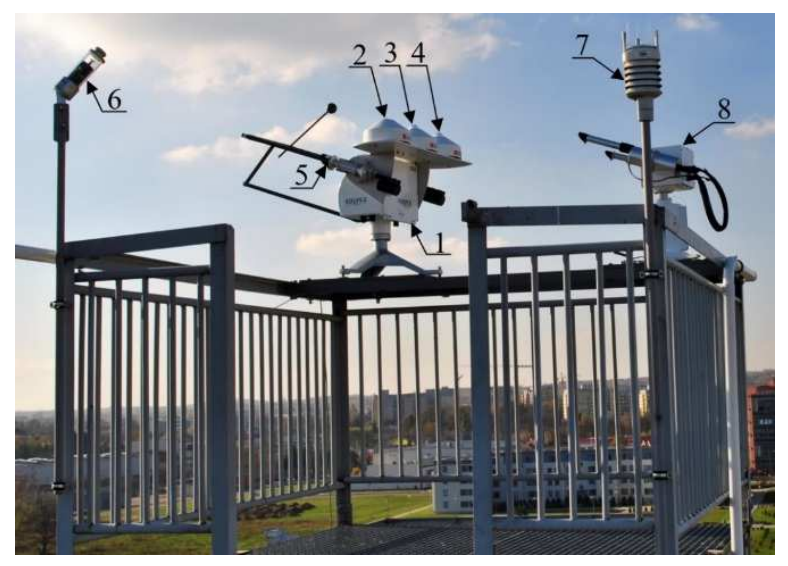

Fig. 1. Laboratory for measurement of solar radiation properties and thermal energy of the atmosphere: 1 - sun tracker, 2 pyrgeometer, 3 - pyranometer, 4 - pyranometer with shading ball, 5 - pyrheliometer, 6 - sunshine duration sensor, 7 - compact weather station, 8 - sky radiometer

Analog and digital signals from measurement equipment are routed to digital multimeter Keithley 2002 and to a desktop computer. The Keithley 2002 is high performance ( $81 / 2$ digit, 28 bit) digital multimeter with built-in 10 channel scanner card connected via GPIB with desktop computer. Measurements are taken at 10 seconds intervals and averaged to 1 minute mean value. The results along with the precise time stamps are written in daily files by means of a custom-written application developed in LabVIEW environment.

\section{Results and disscussion}

This chapter will present examples of measurement results recorded during representative sunny summer day of 30.07.2017 and cloudy fall day of 01.10.2017 in Rzeszow. During sunny day (Fig. 2a) a global horizontal irradiance reached maximum of $\mathrm{GHI}=860 \mathrm{~W} / \mathrm{m}^{2}$ at $12: 15$ local time. Direct horizontal irradiance reached $750 \mathrm{~W} / \mathrm{m}^{2}$ at the same moment and diffuse horizontal irradiance was equal to $76 \mathrm{~W} / \mathrm{m}^{2}$. Thermal radiation from the sky and clouds was almost constant during all day and didn't exceed the range of $325-370 \mathrm{~W} / \mathrm{m}^{2}$. Figure $2 \mathrm{~b}$ presents temperature, relative humidity $(\mathrm{RH})$ and atmospheric pressure variations during a sunny day. 
a)

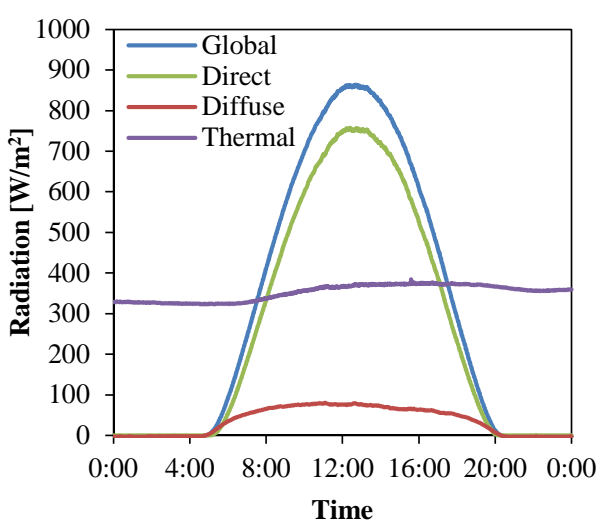

b)

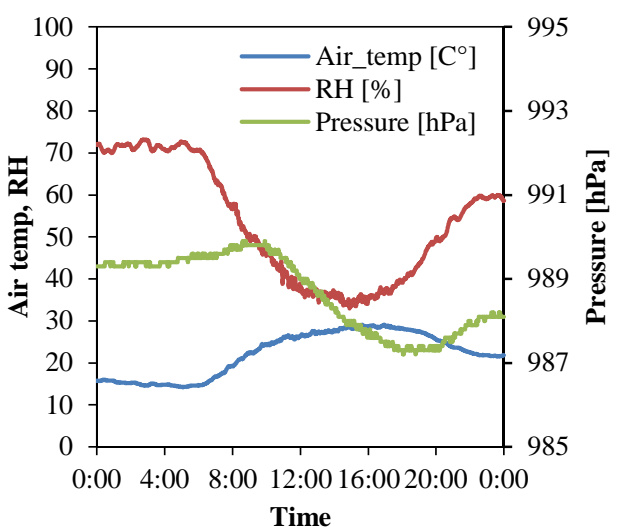

Fig. 2. A sunny day of 30.07.2017: a) solar radiation, b) atmosphere parameters

During cloudy day of 01.10.2017 (Fig. 3a) global, direct and diffuse irradiation were reaching local minima and maxima depending on whether the sun is shaded or not. Figure $3 \mathrm{~b}$ presents temperature, relative humidity (RH) and atmospheric pressure variations during a cloudy day. Daily yields of direct and diffusion irradiance in 2017 are shown in Fig. 4. Maximum values of horizontal global irradiance occur in June and were about $8.5 \mathrm{kWh} / \mathrm{m}^{2} /$ day. Global irradiance in Rzeszów in 2017 was $1100 \mathrm{kWh} / \mathrm{m}^{2} /$ year. The paper [14] present average annual global irradiance in Kołobrzeg: $1064 \mathrm{kWh} / \mathrm{m}^{2} /$ year, Warszawa: 966 $\mathrm{kWh} / \mathrm{m}^{2} /$ year and Zakopane: $988 \mathrm{kWh} / \mathrm{m}^{2} /$ year. The compact weather station that provides variation in air pressure and temperature in 2017 (Fig. 5).

a)

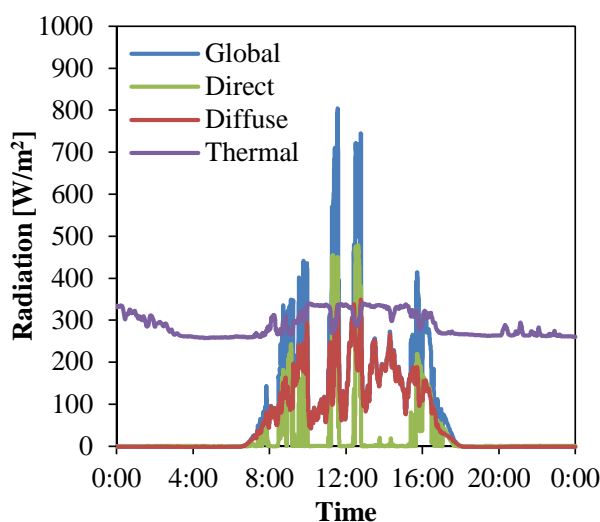

b)

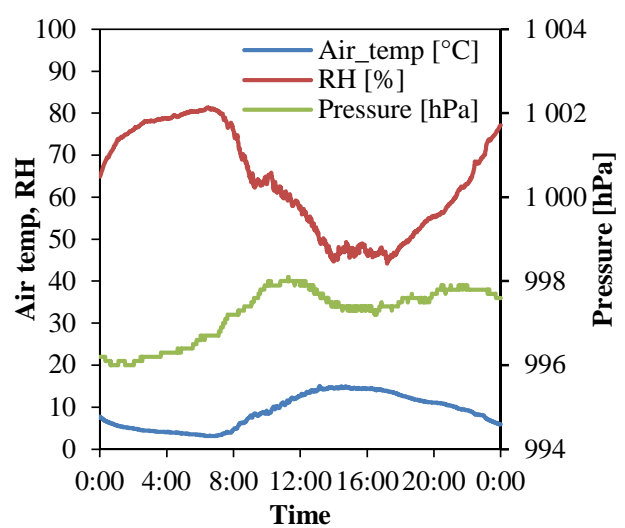

Fig. 3. A cloudy day of 01.10.2017: a) solar radiation, b) atmosphere parameters 


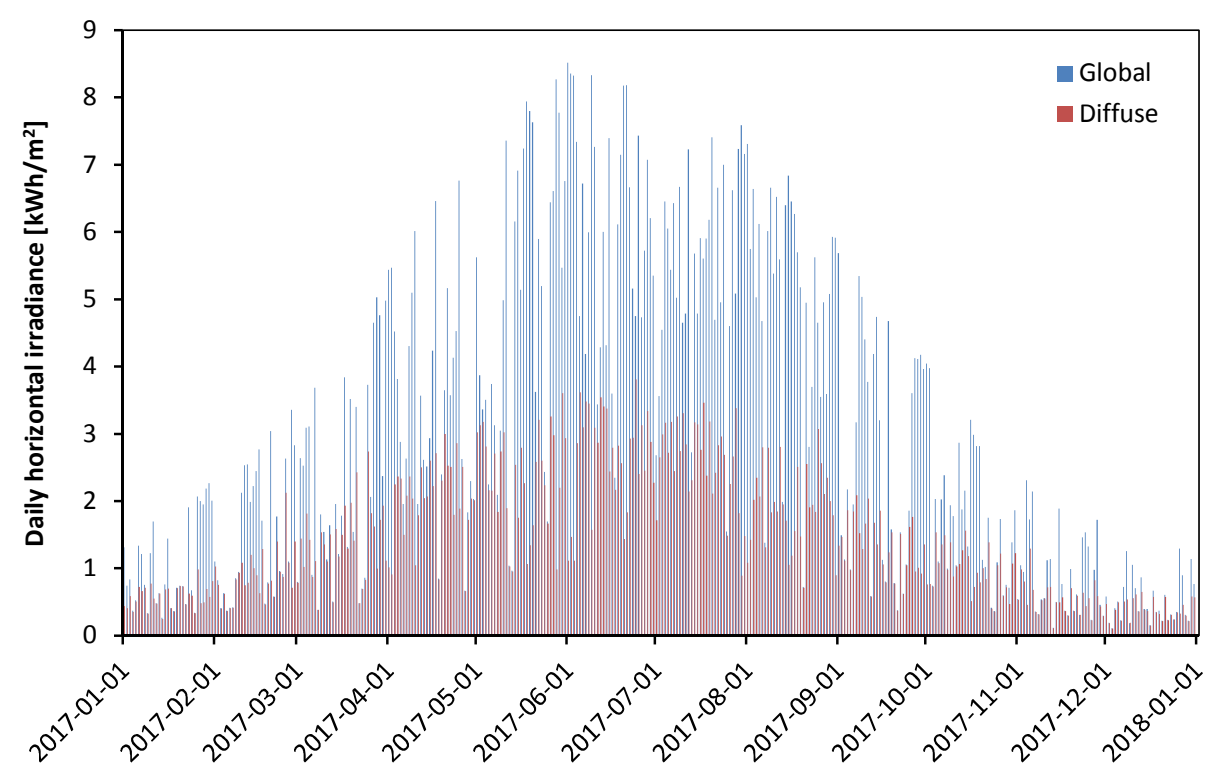

Fig. 4. Daily horizontal global and diffuse irradiance in 2017

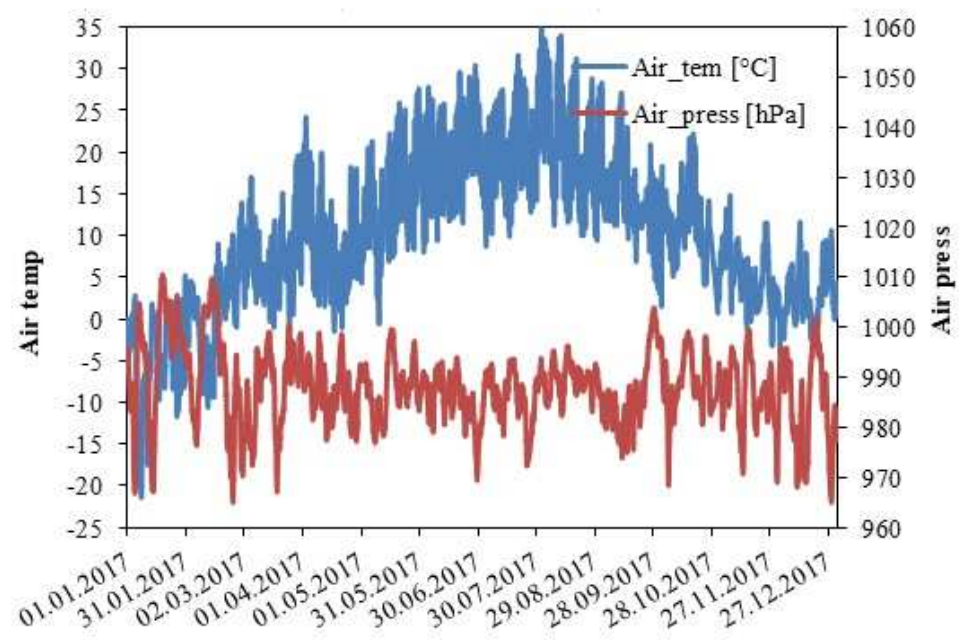

Fig. 5. Daily variation in air pressure and temperature in 2017

\section{Conclusion}

The article presents sample results of measurements of the solar radiation properties and the state of the atmosphere in 2017. By using this laboratory it is possible to determine the instantaneous values of the sun and atmosphere radiation 
and weather conditions. In addition, type and amount of aerosols in the air can be determined.

Global irradiance in 2017 was $1100 \mathrm{kWh} / \mathrm{m}^{2} /$ year, diffuse irradiance was $534.8 \mathrm{kWh} / \mathrm{m}^{2} /$ year, direct irradiance (measured) was $536.4 \mathrm{kWh} / \mathrm{m}^{2} /$ year and thermal irradiance was $2804 \mathrm{kWh} / \mathrm{m}^{2} /$ year. The average air temperature in 2017 was $9.9^{\circ} \mathrm{C}$, average pressure and relative humidity were $988 \mathrm{hPa}$ and $65.5 \%$ respectively.

The presented measurement equipment along with the data acquisition and storage software allow determination of the values of the mean seasonal irradiation, temperature, humidity, wind speed and direction. In the era of renewable energy sources, the presented research equipment enables the optimization of solar systems and determination of efficiency, power and seasonal yields from solar installations, and other devices utilizing renewable energy which is extremely important in their design and operation practice.

\section{References}

[1] Gil P., Szewczyk M.: Roczne badania eksploatacyjne parametrów monokrystalicznych modułów fotowoltaicznych w Rzeszowie, Instal, 4 (2015) 22-27.

[2] Gil P.: Roczne wyniki pomiaru sprawności amorficznych kolektorów fotowoltaicznych w Rzeszowie, Rynek Energii, 4 (2015) 75-83.

[3] Strzelczyk P., Gil P.: Wpływ zaćmienia słońca na produkcję energii elektrycznej przez system fotowoltaiczny, J. Civil Eng. Environ. Archit., 34 (2017) 155-164.

[4] Strzelczyk P., Szczerba Z., Wożniak A.: Modelowanie pionowego profilu prędkości wiatru w tunelu aerodynamicznym, JCEEA, 32 (2015) 413-427.

[5] Gumuła S., Knap T., Strzelczyk P., Szczerba Z.: Energetyka wiatrowa, AGH Uczelniane Wydawnictwo Naukowo-Techniczne, Kraków 2006.

[6] Rehman S., Al-Hadhrami L.M., Alam M.M.: Pumped hydro energy storage system: A technological review. Renewable Sustainable Energy Rev., 44 (2015) 586-598.

[7] Deane J.P., Gallachóir B.Ó., McKeogh E.J.: Techno-economic review of existing and new pumped hydro energy storage plant, Renewable Sustainable Energy Rev., 14 (2010) 1293-1302.

[8] Gil P., Tychanicz M., Wilk J.: Instalacja skojarzonego wytwarzania ciepła i energii elektrycznej ( $\mu \mathrm{CHP}$ ) - badania eksperymentalne parametrów energetycznych, Rynek Energii, 5 (2016) 49-57.

[9] Gałek R., Gil P., Grosicki S., Wolańczyk F.: Wymiennikowy zasobnik ciepła w mikrokogeneracji, ZN PRz Mechanika, 31 (2014) 483-490.

[10] Gil P., Wilk J.: Instalacja CHP z silnikiem spalinowym zasilanym gazem drzewnym, ZN PRz Mechanika, 32 (2015) 217-226.

[11] Gil P., Grosicki S., Wilk J.: Możliwości zastosowań metod oczyszczania gazu powstałego ze zgazowania biomasy w generatorze małej mocy, Instal, 12 (2013) 24-28.

[12] Gil P., Wilk J., Tychanicz M., Wielgos S.: Wstępne badania automatycznego kotła na pellet pod kątem wymagań normy PN-EN 303-5: 2012, Rynek Energii, 5 (2017) 74-79. 
[13] Lewis N.S., Crabtree G.: Basic research needs for solar energy utilization: report of the basic energy sciences workshop on solar energy utilization, Report on the Basic Energy Sciences Workshop on Solar Energy Utilization, April 2005.

[14] Konwersja termiczna energii promieniowania słonecznego w warunkach krajowych, Ekspertyza Komitetu Termodynamiki i Spalania Wydziału IV PAN wykonana pod kierunkiem W. Gogóła, OW PW, Warszawa 1995.

\section{POMIARY WŁAŚCIWOŚCI PROMIENIOWANIA SŁONECZNEGO I ENERGII CIEPLNEJ ATMOSFERY W RZESZOWIE}

Streszczenie

W artykule zaprezentowano pomiary właściwości promieniowania słonecznego i energii cieplnej otoczenia w Rzeszowie $\left(\varphi=50^{\circ} 02^{\prime} \mathrm{N}, \lambda=22^{\circ} 17^{\prime} \mathrm{E}\right)$. Pomiary obejmują promieniowanie słoneczne bezpośrednie, rozproszone i całkowite, dodatkowo mierzone jest promieniowanie cieplne atmosfery. Kompaktowa stacja pogodowa umożliwia pomiar sześciu najważniejszych parametrów pogodowych: ciśnienia powietrza, temperatury, wilgotności, opadów oraz prędkości i kierunku wiatru. SkyRadiometr z dedykowanym układem śledzenia słońca zapewnia wielopasmowe i spektralne pomiary bezpośredniego promieniowania słonecznego i wielopasmowe pomiary rozproszonego promieniowania słonecznego. Obecnie pomiary obejmują okres ponad 4 lat, które można wykorzystać do oszacowania uzysku energii z systemów słonecznych.

Słowa kluczowe: promieniowanie słoneczne, energia odnawialna, pogoda, atmosfera

DOI: 10.7862/rm.2018.44

Otrzymano/received: 17.07.2018

Zaakceptowano/accepted: 26.11 .2018 